\title{
PENGARUH PENERAPAN MODEL PEMBELAJARAN ARCSI DENGAN PENDEKATAN SAINTIFIK TERHADAP MOTIVASI PESERTA DIDIK SMP/MTs.
}

\section{THE INFLUENCE OF APPLICATION ARCSI LEARNING MODEL WITH SCIENTIFIC APPROACH TOWARS MOTIVATION OF JUNIOR HIGH SCHOOL/MTs STUDENTS}

\author{
Usmadi $^{1}$, Ergusni ${ }^{2}$ \\ ${ }^{1,2}$ Universitas Muhammadiyah Sumatera Barat \\ 1,2Jln. Pasir Kandang No.4 Koto Tangah Padang Sumbar, Telp. (0751)-4851002 \\ Email: usmadidttumanggung@gmail.com
}

\begin{abstract}
Abstrak
Penelitian ini merupakan penelitian quasi eksperimen yang bertujuan untuk mengetahui pengaruh penerapan model pembelajaran ARCSI dengan pendekatan saintifik terhadap motivasi peserta didik. Penelitian ini dilaksanakan di kelas VII SMPN 1 kota Bukittinggi, Kelas VII SMPN 1 Ampek Angkek, dan MTs. PPM Diniyah Pasia Ampek Angkek Kabupaten Agam. Kelompok eksperimen diberi perlakuan pembelajaran dengan menerapkan model pembelajaran ARCSI dengan pendekatan saintifik. Temuan dalam penelitian ini adalah terdapat pengaruh penerapan model terhadap motivasi peserta didik yang diperoleh dari angket motivasi belajar matematika kelas VII 1 MTs. PPM Diniyah Pasia, kelas VII SMPN 7 kota Bukittinggi, dan kelas VII 1 SMPN 1 Ampek Angkek kabupaten Agam berkategori efektif dengan mean $=64,39 \%$. Rincian untuk aspek attention $62,29 \%$, relevance $61,33 \%$, confidence $65,86 \%$, dan satisfaction 64,07\%. Kemudian setelah dilakukan uji anova satu jalur disimpulkan bahwa tidak terdapat perbedaan secara signifikan antara motivasi belajar matematika peserta didik kelas VII ${ }_{1}$ MTs. PPM Diniyah Pasia, kelas VII ${ }_{1}$ SMPN 7 kota Bukittinggi, dan kelas VII 1 SMPN 1 Ampek Angkek kabupaten Agam.
\end{abstract}

Kata Kunci: Model Pembelajaran ARCSI, Pendekatan Saintifik, Motivasi Belajar

\begin{abstract}
This study is a quasi experimental research that aims to determine the effect of applying ARCSI learning model with scientific approach to motivation of learners. This research was conducted in class VII of SMPN 1 Bukittinggi city, Class VII SMPN 1 Ampek Angkek, and MTs. PPM Diniyah Pasia Ampek Angkek Kabupaten Agam. The experimental group was treated by applying ARCSI learning model with scientific approach. The findings in this research is that there is influence of application of model to motivation of learners obtained from questionnaire motivation learn mathematics class VII ${ }_{l}$ MTs. PPM Diniyah Pasia, class $V_{I I}$ SMPN 7 Bukittinggi city, and class VII $I_{1}$ SMPN 1 Ampek Angkek regency Agam effective category with mean $=64.39 \%$. Details for attention aspects $62.29 \%$, relevance $61.33 \%$, confidence $65.86 \%$, and satisfaction $64.07 \%$. Then after the one-way anova test was concluded that there is no significant difference between the motivation of learning mathematics students $V I_{1}$ grade MTs. PPM Diniyah Pasia, class VII $I_{1}$ SMP N 7 Bukittinggi city, and class VII $I_{1}$ SMPN 1 Ampek Angkek Agam district.
\end{abstract}

Keywords: ARCSI Learning Model, Scientific Approach, Learning Motivation. 


\section{Pendahuluan}

Berdasarkan UU RI No.20 tentang Sisdiknas tahun 2003, tentang: kebijakan membangun pendidikan adalah untuk menyiapkan generasi muda yang bermutu di masa depan. Kebijakan ini bersifat universal, tanpa mengecualikan warga negara. Arah kebijakan sesuai dengan tujuan pendidikan nasional, yakni berkembangnya potensi peserta didik agar menjadi manusia yang beriman dan bertaqwa kepada Allah Swt., berakhlak mulia, sehat, berilmu, cakap, kreatif, mandiri, dan menjadi warga negara yang demokratis serta bertanggung jawab. Dengan demikian, kemampuan berpikir tingkat tinggi peserta didik dalam pembelajaran perlu dikembangkan untuk mencapai tujuan pendidikan nasional. Berpikir tingkat tinggi dengan situasi yang komplek adalah berpikir matematika dan penalaran, komunikasi, bersikap kritis, interpretasi, refleksi, kreativitas, generalisasi, dan matematisasi (De Lange, 1991)

Fakta pembelajaran di lapangan berupa data dari hasil analisis awal terhadap pelaksanaan proses pembelajaran di SMP/MTs. yakni: (1) proses pembelajaran belum terlaksana dengan baik, (2) proses pembelajaran yang dilaksanakan guru masih bersifat konvensional, (3) belum adanya usaha yang serius dari guru untuk mengubah pola pembelajaran dengan penerapan model-model pembelajaran yang dapat memotivasi, dan mengaktifkan peserta didik selama proses pembelajaran sebagaimana yang diamanatkan kurikulum 2013.

Menurut Direktorat Tenaga Kependidikan Direktorat Jenderal Peningkatan Mutu Pendidik dan Tenaga Kependidikan Departemen Pendidikan Nasional (2008:28) motivasi sangat penting dalam belajar karena motivasi dapat mendorong peserta didik mempersepsi informasi dalam bahan ajar. Sebagus apapun rancangan bahan ajar, jika peserta didik tidak termotivasi maka tidak akan terjadi peristiwa belajar karena peserta didik tidak akan mempersepsi informasi dalam bahan ajar tersebut. Begitu pula yang diungkapkan (Nur,1997) bahwa motivasi berperan dalam menentukan kegiatan alternatif dan memupuk minat yang ada, membuat minat stabil, dan tahan lama. Cara mengajar guru merupakan motivasi bagi peserta didik untuk mencintai pelajaran matematika (Bandura dalam Santrock, 2010:524). Untuk mengatasi problem pembelajaran bisa dilaksanakan dengan berusaha lebih dan mencari strategi yang baik untuk membantu peserta didik, serta dalam proses pembelajaran menganalogikan konsep matematika yang bersifat abstrak ke dalam kehidupan sehari-hari yang dapat dirasakan oleh peserta didik.

Proses pembelajaran matematika dengan model pembelajaran ARCSI dengan pendekatan saintifik ini akan membentuk kemampuan peserta didik dalam menyajikan gagasan dan pengetahuan konkret secara abstrak, menyelesaikan permasalahan abstrak yang terkait, dan berlatih berfikir rasional, kritis dan kreatif. Sebagai bagian dari Kurikulum 2013 yang menekankan pentingnya keseimbangan kompetensi sikap, pengetahuan dan keterampilan. Kemampuan matematika yang dituntut dibentuk melalui pembelajaran berkelanjutan, yakni dimulai dengan meningkatkan pengetahuan tentang metode-metode matematika, dilanjutkan dengan keterampilan menyajikan suatu permasalahan secara matematis dan menyelesaikannya, serta bermuara pada pembentukan sikap jujur, kritis, kreatif, teliti, dan taat asas.

Model pembelajaran ARCSI dengan pendekatan saintifik ini menjabarkan usaha minimal yang harus dilakukan guru dan peserta didik untuk mencapai kompetensi yang diharapkan. Pembelajaran dengan pendekatan saintifik sesuai dengan yang diamanatkan kurikulum 2013, peserta didik diberanikan untuk mencari dari sumber belajar lain yang tersedia dan terbentang luas di sekitarnya. Peran guru sangat penting 
untuk meningkatkan motivasi dan menyesuaikan daya serap peserta didik dengan ketersedian kegiatan pada sintak model pembelajaran ini. Guru dapat memperkayanya dengan kreasi dalam bentuk kegiatan-kegiatan lain yang sesuai dan relevan dengan lingkungan sosial dan alam.

Model pembelajaran ARCSI dengan pendekatan saintifik yang diterapkan mengikuti komponen utama model pembelajaran, yakni:

1. Sintaks:

a. Menarik perhatian peserta didik dengan cara mengkondisikan kelas dengan membaca basmalah (berdoa), mengajak peserta didik dengan ucapan yang baik untuk bekerja dengan cara ikhlas dan selalu mengharapkan keridhaan Allah, serta menayangkan fenomena akan kebesaran Allah Subhanahu Wa Ta'ala. yang sesuai dengan materi ajar.

b. Menjelaskan manfaat pengetahuan, keterampilan atau sikap nilai yang akan dipelajari, serta bagaimana hal tersebut dapat diaplikasikan dalam kehidupan sehari-hari dengan kata-kata atau ucapan yang baik.

c. Musyawarah kelompok dilaksanakan dengan kata-kata atau ucapan yang baik untuk menjalin ukhuwah Islamiyah yakni dengan cara saling menghormati, saling mengambil manfaat, tolong menolong, tidak menonjolkan sikap sombong, tidak merendahkan teman lain dan tidak merasa paling benar.

d. Musyawarah kelas dilaksanakan dengan kata-kata atau ucapan yang baik untuk menjalin ukhuwah Islamiyah yakni dengan cara saling menghormati, saling mengambil manfaat, tolong menolong, tidak menonjolkan sikap sombong, tidak merendahkan teman lain dan tidak merasa paling benar (Islami, mengkomunikasikan (PS 5), attention, relevance, confidence).

e. Memberikan kepuasan kepada peserta didik dengan kata-kata atau ucapan yang baik dengan cara memberikan penguatan yang dapat merangsang pola berpikir peserta didik.

f. Menganalisis dan mengevaluasi proses dan hasil penyelesaian masalah dengan cara memberikan evaluasi secara individu, dan mengingatkan peserta didik untuk selalu bersikap jujur, dan sportif dengan kata-kata atau ucapan yang baik.

g. Menutup pembelajaran menggunakan kata-kata atau ucapan yang baik dengan cara membaca hamdallah, menugasi peserta didik membuat tugas di rumah, mengingatkan/memotivasi peserta didik untuk selalu belajar dengan ikhlas, karena Allah swt. Akan meninggikan derajat orang yang beriman dan berilmu pengetahuan beberapa derajat (Usmadi, 2017)

Menurut (Keller, 1987) seseorang guru boleh mengubah lingkungan pembelajaran agar peserta didik dapat memotivasikan diri mereka sendiri. Sebagai contoh, dalam proses pengajaran dan pembelajaran, kemungkinan terjadi seseorang guru mengajar dengan baik, tetapi peserta didik sebenarnya tidak belajar apa-apa daripadanya. Peserta didik kadangkala merasa berat atau tidak mau belajar sesuatu yang tidak dirasakan bermakna kepada dirinya. Peserta didik hanya menghafal materi ajar dan seringkali melupakan apa yang dipelajarinya setelah selesai mempelajari suatu materi ajar. Peserta didik akan memilih untuk tidak mengaplikasikan apa yang dipelajari, karena tidak berminat dengan apa yang telah dipelajari.

Salah satu strategi motivasi yang khusus untuk bidang pendidikan telah dikembangkan oleh Keller. Keempat komponen strategi motivasi tersebut adalah attention, relevance, confidence dan satisfaction dengan akronim ARCS (Keller, 1987:289-319). Strategi ini menekankan desain bentuk motivasi yang bisa diterapkan 
oleh pendesain ataupun pengajar ke dalam desain bentuk bahan pengajaran. Menurut (Keller, 1984) dan (Visser 1990), "studies evaluating this model in application have provided evidence to support the validity of the four basic constructs and their positive effects on student attitude and performance". Strategi motivasi ARCS merupakan sebuah strategi yang sistematik dalam bentuk motivating instruction (Small, 2000). Strategi motivasi tersebut telah digunakan secara meluas (Means et al. 1997; Shellnut, Knowlton \& Savage 1999; Song \& Keller 2001; Hyland 2006). Strategi ARCS juga telah diaplikasikan dalam beberapa jenis pengaturan pengajaran (instructional settings) tertentu seperti computer-based instruction (Keller \& Suzuki, 2004), textual material (Keller et al, 1987), instructor-led formal lecture (Visser et al, 1990) dan online assessment (Hyland, 2006). Motivasi peserta didik terhadap pembelajaran matematika yang dikumpulkan dalam peneltian ini terkait dengan (a) Attention (Perhatian), (b) Relevance (relevansi), (c) Confidence (Keyakinan), (d) Satisfaction (Kepuasan).

Tujuan utama dalam penelitian ini adalah untuk mengetahui pengaruh penerapan model ARCSI dengan pendekatan sainstifik terhadap motivasi belajar matematika siswa SMPN 1 kota Bukittinggi.

\section{Metode Penelitian}

Jenis penelitian ini adalah eksperimen semu, dengan populasi peserta didik kelas VII SMP Negeri 7 kota Bukittinggi dan kelas VII SMP Negeri 1 Tanjung Alam kabupaten Agam. Instrumen penelitian yang digunakan adalah angket motivasi belajar peserta didik dalam model pembelajaran ARCSI dengan pendekatan saintifik. Kisi-kisi angket motivasi belajar dapat dilihat pada Tabel berikut ini.

Tabel 1. Kisi-kisi Angket Motivasi Belajar Matematika dalam Model Pembelajaran ARCSI dengan Pendekatan Saintifik

\begin{tabular}{cccc}
\hline Sub Variabel & Indikator & \multicolumn{2}{c}{ Nomor Pernyataan } \\
\cline { 2 - 4 } & & Positif & Negatif \\
\hline Motivasi & Attention & $1,2,4,6,26,28$ & $7,17,20$ \\
\cline { 2 - 4 } Terhadap Materi & Relevance & $9,10,16$ & 5 \\
\cline { 2 - 4 } dan Proses & Confidence & $3,12,13,33$ & $14,31,34$ \\
Pembelajaran & Satisfaction & $18,19,21,22,23,24,25$, & 11,15 \\
Matematika & & $27,29,30,32,35$ & \\
\hline
\end{tabular}

Data hasil angket motivasi belajar matematika peserta didik ketiga kelas eksperimen dianalisis dengan statistik Anova satu jalur, tujuannya untuk melihat perbedaan motivasi belajar matematika peserta didik untuk masing- masing kelas sampel.

\section{Hasil dan Pembahasan}

Angket motivasi belajar matematika dalam model pembelajaran ARCSI dengan pendekatan saintifik diisi oleh peserta didik kelas eksperimen 1 sebanyak 20 orang, peserta didik eksperimen II sebanyak 28 orang, dan peserta didik eksperimen III sebanyak 20 orang. Berikut ini digambarkan hasil angket motivasi belajar matematika menurut peserta didik pada masing- masing kelas eksperimen pada Tabel 2 berikut ini. 
Tabel 2. Hasil Analisis Angket Motivasi Belajar Peserta Didik Kelas VII MTs. PPM Diniyah Pasia Ampek Angkek dalam Model Pembelajaran ARCSI dengan Pendekatan Saintifik pada Kelas Eksperimen

\begin{tabular}{ccccccc}
\hline \multirow{2}{*}{ No. } & Indikator & \multicolumn{2}{c}{ Nomor Pernyataan } & Mean & $\%$ & \multirow{2}{*}{ Kategori } \\
\cline { 2 - 4 } & \multicolumn{1}{c}{ Positif } & Negatif & & & \\
\hline 1. & Attention & $1 ; 2 ; 4 ; 6 ; 26 ; 28$ & $17 ; 20 ; 7$ & 3,46 & 61,67 & Efektif \\
\hline 2. & Relevance & $9 ; 10 ; 16$ & 5 & 3,03 & 57,25 & Efektif \\
\hline 3. & Confidence & $3 ; 12 ; 13 ; 33$ & $14 ; 31 ; 34$ & 3,59 & 64,57 & Efektif \\
\hline 4. & Satisfaction & $8 ; 18 ; 19 ; 21 ; 22 ; 23 ;$ & $11 ; 15$ & 3,6 & 64,33 & Efektif \\
& & & & & \\
\hline \multicolumn{7}{c}{$24 ; 25 ; 27 ; 29 ; 30 ; 32 ; 35$} \\
\hline
\end{tabular}

Tabel 3. Hasil Analisis Angket Motivasi Belajar Peserta Didik Kelas VII

SMP N 7 Kota Bukittinggi dalam Model Pembelajaran ARCSI dengan Pendekatan Saintifik pada Kelas Eksperimen

\begin{tabular}{|c|c|c|c|c|c|c|}
\hline \multirow{2}{*}{ No. } & \multirow{2}{*}{ Indikator } & \multicolumn{2}{|c|}{ Nomor Pernyataan } & \multirow[t]{2}{*}{ Mean } & \multirow[t]{2}{*}{$\%$} & \multirow[t]{2}{*}{ Kategori } \\
\hline & & Positif & Negatif & & & \\
\hline 1. & Attention & $1 ; 2 ; 4 ; 6 ; 26 ; 28$ & $17 ; 20 ; 7$ & 4.04 & 80,72 & $\begin{array}{l}\text { Sangat } \\
\text { Efektif }\end{array}$ \\
\hline 2. & Relevance & $9 ; 10 ; 16$ & 5 & 3,70 & 80,21 & $\begin{array}{l}\text { Sangat } \\
\text { Efektif }\end{array}$ \\
\hline 3. & Confidence & $3 ; 12 ; 13 ; 33$ & $14 ; 31 ; 34$ & 3,96 & 76,42 & $\begin{array}{l}\text { Sangat } \\
\text { Efektif }\end{array}$ \\
\hline 4. & Satisfaction & $\begin{array}{c}8 ; 18 ; 19 ; 21 ; 22 ; 23 ; \\
24 ; 25 ; 27 ; 29 ; 30 ; 32 ; 3 \\
5\end{array}$ & $11 ; 15$ & 4.17 & 75,10 & $\begin{array}{l}\text { Sangat } \\
\text { Efektif }\end{array}$ \\
\hline & Mean & & & 3,97 & 78,12 & $\begin{array}{l}\text { Sangat } \\
\text { Efektif }\end{array}$ \\
\hline
\end{tabular}

Tabel 4. Hasil Analisis Angket Motivasi Belajar Peserta Didik Kelas VII SMP N 1 Ampek Angkek Kabupaten Agam dalam Model Pembelajaran ARCSI dengan Pendekatan Saintifik pada Kelas Eksperimen

\begin{tabular}{ccccccc}
\hline \multirow{2}{*}{ No. } & \multirow{2}{*}{ Indikator } & \multicolumn{2}{c}{ Nomor Pernyataan } & Mean & $\%$ & Kategori \\
\cline { 3 - 4 } & & Positif & Negatif & & & \\
\hline 1. & Attention & $1 ; 2 ; 4 ; 6 ; 26 ; 28$ & $17 ; 20 ; 7$ & 3,56 & 56,49 & Efektif \\
\hline 2. & Relevance & $9 ; 10 ; 16$ & 5 & 2,99 & 46,52 & $\begin{array}{l}\text { Kurang } \\
\text { Efektif }\end{array}$ \\
\hline 3. & Confidence & $3 ; 12 ; 13 ; 33$ & $14 ; 31 ; 34$ & 3,63 & 56,60 & Efektif \\
\hline 4. & Satisfaction & $8 ; 18 ; 19 ; 21 ; 22 ;$ & $11 ; 15$ & 3,62 & 52,77 & efektif \\
& $23 ; 24 ; 25 ; 27 ;$ & & & & \\
\hline & $29 ; 30 ; 32 ; 35$ & & & & \\
\hline \multicolumn{7}{c}{ Mean } \\
\hline
\end{tabular}

Berdasarkan Tabel 2, Tabel 3, dan Tabel 4, terlihat bahwa rata-rata persentase keefektifan motivasi belajar matematika peserta didik kelas eksperimen dalam Model Pembelajaran ARCSI dengan Pendekatan Saintifik dengan empat indikator motivasi, yakni: attention $66,29 \%$, relevance $61,33 \%$, confidence $65,86 \%$, dan satisfaction 
64,07\%, diperoleh mean keempat indikator tersebut untuk masing-masing kelompok eksperimen adalah: eksperimen 1 pada MTs. PPM. Diniyah Pasia Ampek Angkek 61,96\%, SMPN 7 Kota Bukittinggi 78,12\%, dan SMPN 1 Ampek Angkek 53,10\%.

Simpulan persentase keefektifan motivasi belajar peserta didik dalam Model Pembelajaran ARCSI dengan Pendekatan Saintifik pada kelas eksperimen dapat dilihat pada Tabel 5 dan Gambar 1 berikut ini.

Tabel 5. Ringkasan Hasil Analisis Angket Motivasi Belajar Matematika Peserta Didik Dalam Model Pembelajaran ARCSI dengan Pendekatan Saintifik Pada Kelas Eksperimen

\begin{tabular}{|c|c|c|c|c|c|c|}
\hline \multirow[t]{2}{*}{ No. } & \multirow[t]{2}{*}{ Indikator } & \multicolumn{2}{|c|}{ Nomor Pernyataan } & \multirow{2}{*}{ Mean } & \multirow{2}{*}{$\%$} & \multirow{2}{*}{ Kategori } \\
\hline & & Positif & Negatif & & & \\
\hline 1. & Attention & $1 ; 2 ; 4 ; 6 ; 26 ; 28$ & $17 ; 20 ; 7$ & 3,67 & 66,29 & Efektif \\
\hline 2. & Relevance & $9 ; 10 ; 16$ & 5 & 3,25 & 61,33 & $\begin{array}{l}\text { Kurang } \\
\text { Efektif }\end{array}$ \\
\hline 3. & Confidence & $3 ; 12 ; 13 ; 33$ & $\begin{array}{c}14 ; 31 \\
34\end{array}$ & 3,73 & 65,86 & Efektif \\
\hline 4. & Satisfaction & $\begin{array}{c}8 ; 18 ; 19 ; 21 ; 22 ; \\
23 ; 24 ; 25 ; 27 ; 29 ; \\
30 ; 32 ; 35\end{array}$ & $11 ; 15$ & 3,80 & 64,07 & efektif \\
\hline & & Mean & & 3,61 & 64,39 & efektif \\
\hline
\end{tabular}

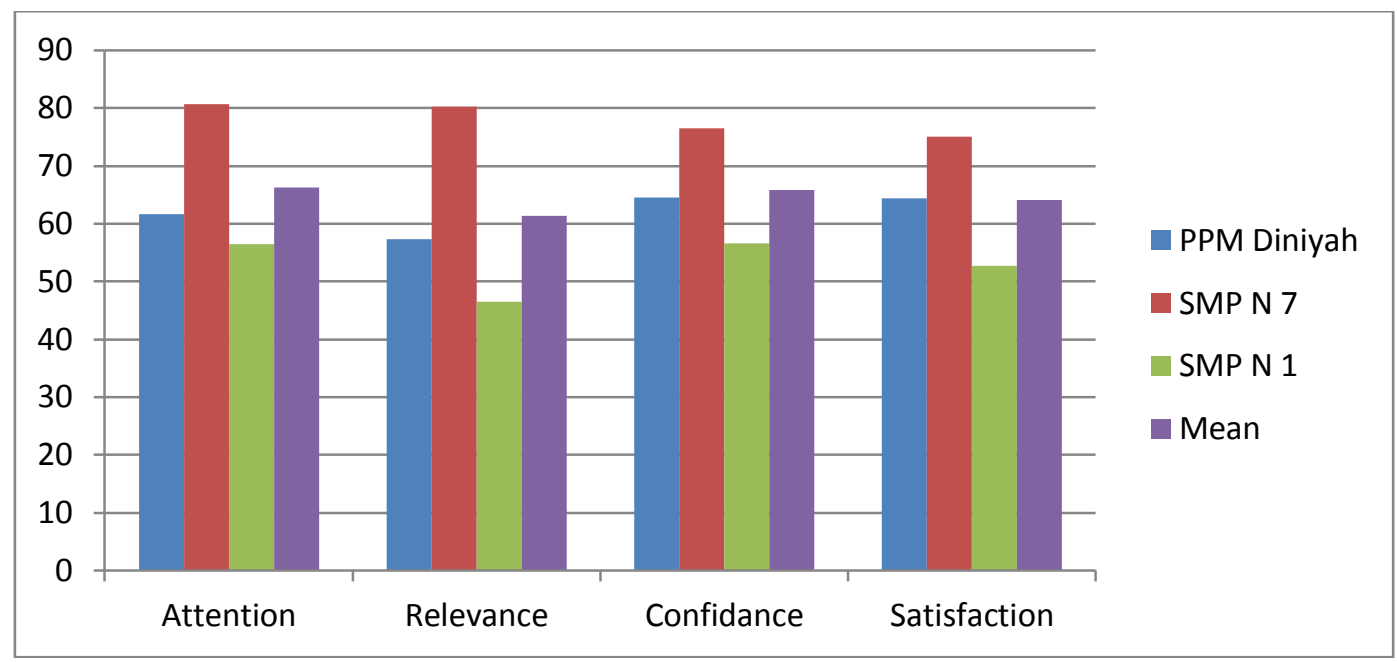

Gambar 1. Keefektifan Motivasi Belajar Matematika Peserta Didik Kelas Eksperimen pada Model Pembelajaran ARCSI dengan Pendekatan Saintifik

Selanjutnya data hasil angket motivasi belajar matematika peserta didik ketiga kelas eksperimen dianalisis dengan statistik Anova satu jalur tujuannya untuk melihat perbedaan motivasi belajar matematika peserta didik untuk masing- masing kelas eksperimen. Hasil analisis data dapat dilihat pada Tabel 6 berikut ini. 
Tabel 6. Ringkasan Anova Satu Jalur

\begin{tabular}{cccccc}
\hline Sumber Variansi & \multirow{2}{*}{$\mathrm{Db}$} & $\mathrm{JK}$ & $\mathrm{RJK}$ & $\mathrm{F}_{\text {Hitung }}$ & $\mathrm{F}_{\text {Tabel }}$ \\
\hline Kelompok (A) & 2 & 5199,54571 & 2599,77 & 0,011495524 & 3,143 \\
\hline Dalam (D) & 64 & 14473934,2 & 226155,22 & & \\
\hline Total Di Koreksi (TR) & 66 & 14479133,8 & & & \\
\hline
\end{tabular}

Pengujian Hipotesis:

$H_{0}: \mu_{a}=\mu_{b}=\mu_{c}$

$H_{1}: \mu_{a} \neq \mu_{b}=\mu_{c}$

Diperoleh: Fhitung $=0,0115<3,143=\mathrm{F}(0,05 ; 2 ; 64)$

Jadi disimpulkan : Tidak terdapat perbedaan motivasi belajar matematika antara peserta didik MTs. PPM Diniyah Moderen Kelas VII ${ }_{1}$, Peserta didik Kelas VII-1 SMPN 7 Kota Bukittinggi, dan Peserta didik kelas VII 1 SMPN 1 Ampek Angkek Kabupaten Agam.

\section{Kesimpulan}

Tingkat efektivitas dari Model Pembelajaran ARCSI dengan Pendekatan Saintifik yang diperoleh dari angket motivasi belajar matematika kelas VII ${ }_{1}$ MTs. PPM

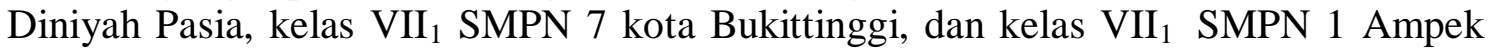
Angkek kabupaten Agam berkategori efektif dengan mean $=64,39 \%$ dengan rincian untuk aspek attention $62,29 \%$, relevance $61,33 \%$, confidence $65,86 \%$, dan satisfaction 64,07\%. Kemudian setelah dilakukan uji anova satu jalur disimpulkan bahwa tidak terdapat perbedaan secara signifikan antara motivasi belajar matematika peserta didik kelas VII 1 MTs. PPM Diniyah Pasia, kelas VII $_{1}$ SMPN 7 kota Bukittinggi, dan kelas $\mathrm{VII}_{1}$ SMPN 1 Ampek Angkek kabupaten Agam.

\section{Daftar Pustaka}

Depdiknas. (2008a) Panduan Pengembangan Buku Peserta Didik. Jakarta: Dirjen Pendidikan Dasar dan Menengah.

Depdiknas. (2008 $)$ Pengembangan Rencana Pelaksanaan Pembelajaran (RPP). Jakarta: Dirjen Pendidikan Dasar dan Menengah.

Hyland, P. (2006). A Case Study of Online Assessment for Basic Mathematics to Motivate Learners and Enhance Learning. Http://Www.Pi.Ac.Ae/ Metsmac /Proceedings /2006/ Hyland-P-Metsmac 2006. pdf . [15 Agustus 2015]

Ibrahim, M. (2000). Pembelajaran Kooperatif. Surabaya: UNESA-University Press.

Keller, J. M., \& Suzuki, K. (1988). Use of The ARCS Motivation Model in Courseware Design. Dlm. Jonassen, D. H. (Pnyt.). Instructional Designs For Microcomputer Courseware, Lawrence Erlbaum Associates, Hillsdale NJ, hal. 401- 434.

Keller, J. M., \& Suzuki, K. (2004). Learner Motivation and E-Learning Design: A Multinationally Validated Process. Journal of Education Media, 29 (3), 
175-189. Tersedia Pada Http//Www.Arcsmodel.Com. Didownload Tanggal 14 April 2014.

Keller, J. M., (1987a). Development and Use of The ARCS Model of Motivational Design. Journal of Instructional Development 10(3), hal. 2-10.

Keller, J. M., (1987b) Strategies for Stimulating The Motivation to Learn. Performance and Instruction Journal 26(8), hal. 1-7.

Keller, J. M., (1987c). The Systematic Process of Motivational Design. Performance and Instruction Journal 25(7), hal. 1-8.

Means, T. B., Jonassen, D. H., \& Dwyer, F. M., (1997). Enhancing Relevance. Embedded ARCS Strategies Vs. Purpose. Educational Technology, Research \& Development 45, hal. 5-17.

Muri, Y. A., (2014). Metodologi Penelitian: Kuantitatif, Kualitatif dan Penelitian Gabungan (Mixed Research). Jakarta; Prenadamedia Group.

Nur, M. (1997). Teori Pembelajaran Kognitif. IKIP Surabaya.

Plomp, T. (2013). Educational Design Research : An Introduction, in An Introduction to Educational Research. Enschede, Netherland : National Institute for Curriculum Development.

Santrock, J. W., (2010). Educational Psychologi, Ed. 2.Dialih Bahasakan Oleh Tri Wibowo B.S., Psikologi Pendidikan (Jakarta: Kencana 2010).

Shellnut, B., Knowlton, A., \& Savage, T. (1999). Applying The ARCS Model to The Design and Development of Computer-Based Modules for Manufacturing Engineering Courses. Educational Technology, Research and Development 47, hal. 100-110.

Small, R. (2000). Motivation in Instructional Design. Teacher Librarian 27(5), 29-31.

Song, S. H., \& Keller, J. M., (2001). Effectiveness of Motivationally Adaptive Computer-Assisted Instruction on The Dynamic Aspects of Motivation. Educational Technology, Research and Development 49, 5-22.

Usmadi. (2017). Pengembangan Model Pembelajaran ARCSI Dengan Pendekatan Saintifik, Disertasi (Tidak Dipublikasikan). Universitas Negeri Padang.

Visser, J. \& Keller, J. M., (1990). The Clinical Use of Motivational Message: An Inquiry Into The Validity of The ARCS Model of Motivational Design. Instruct. Science, 19, 2011, hal. 467-599.

Tim Revisi. (2014). Panduan Penulisan Disertasi Program Doktor (S-3). Edisi Revisi. Pascasarjana Universitas Negeri Padang. Padang. 